\title{
Marcin Bogdański
}

Uniwersytet Warmińsko-Mazurski w Olsztynie

e-mail: marcin.bogdanski@uwm.edu.pl

\section{EWOLUCJA BAZY EKONOMICZNEJ A WZROST GOSPODARCZY MIAST WOJEWÓDZKICH EVOLUTION OF ECONOMIC BASE VS. ECONOMIC GROWTH OF VOIVODSHIP CITIES}

DOI: $10.15611 /$ pn.2018.536.02

JEL Classification: R110

Streszczenie: Podstawowym celem prezentowanych analiz było określenie wielkości, struktury oraz poziomu zróżnicowania bazy ekonomicznej miast wojewódzkich w Polsce. Zbadano także relacje między zmianami wielkości i struktury bazy ekonomicznej a poziomem wzrostu gospodarczego mierzonego wartością PKB per capita. Uzyskane wyniki pozwalają stwierdzić, że większymi rozmiarami sektora egzogenicznego, tak w ujęciu względnym, jak i bezwzględnym, charakteryzowały się miasta duże. W przypadku tych ośrodków w strukturze bazy ekonomicznej dominowały usługi rynkowe. Wraz ze spadkiem rozmiarów miasta z reguły malała także liczba osób pracujących w działalności egzogenicznej, a w jej strukturze zwiększał się udział usług nierynkowych. $Z$ analiz wynika także, że rozmiar i struktura bazy ekonomicznej miały wpływ na poziom wzrostu gospodarczego. Poziom PKB per capita był najwyższy w miastach o dużej liczbie pracujących w sektorze egzogenicznym i dominującym znaczeniu usług rynkowych.

Słowa kluczowe: miejska baza ekonomiczna, wzrost gospodarczy, miasta wojewódzkie.

Summary: The main purpose of the presented analyzes was to determine the size, structure and level of diversification of the economic base of voivodship cities in Poland. The relationship between changes in the size and structure of the economic base and the level of economic growth measured by the value of GDP per capita was also examined. The obtained results allow to conclude that the large size of the exogenous sector, both in relative and absolute terms, was characteristic for large cities. In the case of these cities, market services prevailed in the structure of the economic base. Along with the decline in the size of the city, generally, the number of people working in exogenous activity also decreased, and in its structure the share of non-market services increased. The analyzes also show that the size and structure of the economic base had an impact on the level of economic growth. The level of GDP per capita was the highest in the case of cities with a large number of employees in the exogenous sector, with the dominant importance of market services.

Keywords: urban economic base, economic growth, voivodship cities. 


\section{Wstęp}

Miasta, szczególnie duże, stanowią ważne ogniwa systemów osadniczych i szerzej systemów społeczno-gospodarczych. W wymiarze gospodarczym rola ośrodków miejskich polega na wyznaczaniu lokalizacji działalności gospodarczej, integracji procesów gospodarczych oraz kształtowaniu warunków materialnych życia ludności [Skrzyp 2002, s. 18]. Ponadto ich względnie równomierne rozmieszczenie w przestrzeni jest czynnikiem sprzyjającym podnoszeniu efektywności gospodarczej i równości społecznej, ograniczaniu dysproporcji w poziomie wzrostu gospodarczego oraz racjonalnemu gospodarowaniu zasobami przyrody [Korcelli 2007, s. 98]. Wskazanie czynników determinujących różnice w poziomie oraz dynamice wzrostu gospodarczego ośrodków miejskich może zatem przyczynić się do zrozumienia niektórych mechanizmów kształtujących poziom regionalnych dysproporcji gospodarczych.

Podstawowym celem prezentowanych analiz było określenie wielkości, struktury oraz poziomu zróżnicowania bazy ekonomicznej miast wojewódzkich w Polsce. $\mathrm{W}$ teoriach z zakresu ekonomii, nauk regionalnych oraz geografii ekonomicznej przyjmuje się, że rozmiar i struktura bazy ekonomicznej to jednen z czynników determinujących poziom i dynamikę wzrostu gospodarczego jednostek przestrzennych na poziomie regionalnym i lokalnym. Dodatkowym celem analiz było więc określenie, czy w badanym okresie można było mówić o występowaniu dodatniej zależności pomiędzy powyższymi kategoriami ekonomicznymi, tj. bazą ekonomiczną a poziomem wzrostu gospodarczego dużych miast w Polsce. Potwierdzenie istnienia związku między tymi zmiennymi może przyczynić się do lepszego zrozumienia uwarunkowań wzrostu gospodarczego wybranych ośrodków miejskich. Może także stanowić podstawę do prowadzenia bardziej efektywnej polityki wzrostu i rozwoju gospodarczego dużych miast, tak na szczeblu lokalnym, jak i regionalnym oraz centralnym. W obu przypadkach należy bowiem poznać specyfikę gospodarek badanych jednostek, trafnie określić strukturę funkcjonalną miast oraz ich zmiany w czasie [Sridhar 2017, s. 63-64].

\section{Teoria bazy ekonomicznej}

Teoria bazy ekonomicznej należy do koncepcji o względnie długiej tradycji. Za symboliczną datę jej powstania przyjmuje się rok 1902, kiedy W. Sombart - niemiecki ekonomista, socjolog i historyk gospodarczy - opisuje jej podstawowe twierdzenia w dziele pt. Der Moderne Kapitalismus (niem. Nowoczesny kapitalizm). Okres szczególnie dynamicznego rozwoju tej koncepcji przypada jednak na drugą połowę XX w. Wtedy też wnioski z tej teorii zaczęto powszechnie wykorzystywać w praktyce zarządzania i strategicznego planowania rozwoju ośrodków miejskich [Sokołowski 2008, s. 246].

W myśl teorii miejskiej bazy ekonomicznej miasto rozpatrywane jest w kategorii systemu wzajemnie z sobą powiązanych i oddziałujących na siebie podmiotów go- 
spodarczych. Działalność gospodarczą prowadzoną na terenie miasta dzieli się na dwie grupy, sektory produkcji. Na sektor pierwszy (egzogeniczny, podstawowy, miastotwórczy) składają się te rodzaje działalności, których efekty w postaci gotowych produktów lub usług są sprzedawane podmiotom zlokalizowanym poza miastem. W ramach drugiego sektora (endogenicznego, obsługowego, uzupełniającego) wytwarzane są dobra służące zaspokojeniu potrzeb podmiotów zlokalizowanych na terenie miasta. Są one zatem sprzedawane lokalnie [Knapik 2010, s. 32; Sokołowski 2008, s. 246].

Czynnikiem umożliwiającym wzrost i rozwój gospodarczy ośrodków miejskich jest stały rozwój skali działalności egzogenicznej. Powoduje to wzrost dochodów podmiotów gospodarczych w nią zaangażowanych (przedsiębiorstw, gospodarstw domowych), co w efekcie zwiększa popyt inwestycyjny i konsumpcyjny. Wzrost skali i zakresu potrzeb zgłaszanych w mieście sprzyja pojawieniu się nowych przedsiębiorstw oraz rozszerzeniu skali działalności już istniejących producentów. Początkowy impuls w postaci wzrostu skali działalności egzogenicznej uruchamia procesy mnożnikowe, których globalny efekt będzie większy niż początkowo podjęta działalność [Stawasz 2016, s. 39]. Zatem wartość produkcji wytwarzanej lokalnie zależy od wartości przychodów pochodzących z eksportu dóbr na rynki pozalokalne oraz tempa obiegu tych przychodów pomiędzy lokalnymi podmiotami. Im przychody z działalności egzogenicznej będą szybciej rosły, tym większe są możliwości dynamicznego rozwoju miast [Rutland, O'Hagan 2007, s. 165].

Względna prostota wniosków płynących z teorii miejskiej bazy ekonomicznej przyczyniła się do wzrostu jej popularności jako narzędzia planowania i zarządzania wzrostem gospodarczym obszarów miejskich. Mimo rodzących się wątpliwości w jej aktualność oraz jej zdolność do wyjaśniania procesów wzrostu gospodarczego miast, szczególnie wobec postępującej złożoności gospodarki światowej oraz jej ewolucji w kierunku gospodarki opartej na wiedzy [zob. m.in.: Krikelas 1992; Christofakis, Gkouzos 2014; Markusen 2007; Rutland, O’Hagan 2007], w literaturze przedmiotu można spotkać się z poglądem, że istnieją wyłącznie dwie sprawdzone teorie w sposób kompleksowy wyjaśniające uwarunkowania funkcjonalnego rozwoju miast - teoria ośrodków centralnych i jej pochodne oraz teoria bazy ekonomicznej [Walkiewicz 2006, s. 26].

\section{Cel, metody badawcze i zakres czasowy badań}

Podstawowym celem prezentowanych analiz było określenie wielkości, struktury oraz poziomu dywersyfikacji bazy ekonomicznej miast wojewódzkich ${ }^{1}$ w Polsce i ich ewolucji w czasie. Uwzględniając teoretyczne rozważania nad znaczeniem

${ }^{1} \mathrm{~W}$ przypadku województw kujawsko-pomorskiego i lubuskiego, gdzie siedziby wojewody oraz sejmiku województwa znajdują się w różnych miastach (odpowiednio: Bydgoszcz i Toruń oraz Gorzów Wielkopolski i Zielona Góra), do analizy przyjęto po dwa miasta. Analiza obejmuje więc 18 ośrodków miejskich. 
bazy ekonomicznej w stymulowaniu wzrostu gospodarczego miast, przed analizami postawiono dodatkowy cel, który polegał na weryfikacji hipotezy o występowaniu powyższego związku dla badanych miast. W hipotezie założono, że miasta, które charakteryzowały się relatywnie większymi rozmiarami bazy ekonomicznej, znajdowały się jednocześnie na względnie wyższym poziomie wzrostu gospodarczego.

Kluczowym problemem w tego typu analizach jest wybór metod i wskaźników, za pomocą których dokonywany jest pomiar wielkości oraz poziomu zróżnicowania miejskiej bazy ekonomicznej i poziomu wzrostu gospodarczego. W pierwszym przypadku dokonano tego przy użycia wskaźnika nadwyżki pracowników oraz wskaźnika specjalizacji lokalnej. Są to powszechnie stosowane, pośrednie metody pomiaru wielkości bazy ekonomicznej, które mimo swych ograniczeń pozwalają na precyzyjne określenie skali działalności prowadzonej w ramach funkcji egzogenicznej. Stopień zróżnicowania bazy ekonomicznej określono za pomocą wskaźnika Amemiya ${ }^{2}$. Posłużono się przy tym danymi o liczbie pracujących w głównym miejscu pracy (na dzień 31 XII) w podziale na sekcje PKD 2007. Punktem odniesienia do obliczeń była sumaryczna liczba i struktura pracujących w całym kraju.

Poziom wzrostu gospodarczego określono za pomocą wskaźnika PKB per capita. Jest to jedna z najczęściej stosowanych miar, która w sposób syntetyczny obrazuje efekty działalności gospodarczej na obszarze badanych jednostek przestrzennych. Pomimo swojej prostoty miernik ten pozwala na uwzględnienie m.in.: struktury działalności gospodarczej, struktury nakładów czynników produkcji, relacji cen oraz czynników demograficznych [Strahl 2009, s. 17]. Stąd jest on powszechnie wykorzystywany do pomiaru poziomu wzrostu gospodarczego zarówno na potrzeby opracowań naukowych, jak i polityki gospodarczej. Ze względu na brak publikacji przez Główny Urząd Statystyczny danych o wartości PKB per capita na poziomie miast, w pracy posłużono się danymi o jego wartości dla podregionów NUTS-3, w których analizowane ośrodki są położone.

Okres analizy obejmuje lata 2008 i 2015, a większość danych pochodziła z Banku Danych Lokalnych GUS. Dane o liczbie pracujących w miastach wojewódzkich zostały kupione w Departamencie Informacji GUS.

\section{Wyniki badań}

Badane miasta, ze względu na funkcje pełnione w krajowym systemie administracyjnym, należą do najważniejszych ośrodków miejskich w Polsce. W 2008 r. zamieszkiwało je 7703 tys. osób, co stanowiło 20,2\% populacji kraju i 33,1\% ludności miejskiej. W roku 2015 liczba osób zamieszkujących analizowane ośrodki zmalała

${ }^{2}$ Biorąc pod uwagę ograniczenia objętościowe pracy oraz powszechne wykorzystanie w literaturze przedmiotu wymienionych miar bazy ekonomicznej, zrezygnowano z prezentacji w treści artykułu szczegółowego opisu obliczania ich wartości oraz ograniczeń interpretacyjnych. Obszerne omówienie tych zagadnień znajduje się m.in. w: [Jerczyński 1971; Dacko 2008; Sokołowski 2008; Knapik 2010; Sridhar 2017]. 
do 7686 tys. (19,9\% ludności Polski, 33,2\% ogółu ludności miejskiej). Jednocześnie pracowała w nich ponad jedna trzecia ogółu pracujących w Polsce (odpowiednio $34,3 \%$ w 2008 r. i 33,6\% siedem lat później) oraz ponad $40 \%$ wszystkich pracujących w miastach $(40,3 \%$ w 2008 r. i 41,4\% w 2015). Udział 6 wybranych miast (Warszawy, Krakowa, Łodzi, Wrocławia, Poznania i Szczecina) w tworzeniu krajowego PKB wyniósł $24,8 \%$ w roku 2008 i $25,2 \%$ w $2015^{3}$. Mają więc one także szczególne znaczenie w krajowym systemie społeczno-gospodarczym. Stanowiło to dodatkową przesłankę do takiego doboru próby badawczej.

$\mathrm{W}$ tabeli 1 przedstawiono dane o wielkości bazy ekonomicznej badanych miast wyrażone liczbą osób pracujących w sektorze egzogenicznym, a także procentowym jej udziałem w całkowitej liczbie ludności w latach 2008 i 2015.

$\mathrm{W}$ obu badanych latach zdecydowanie największymi rozmiarami zatrudnienia egzogenicznego, tak w ujęciu względnym, jak i bezwzględnym, charakteryzowała się Warszawa. Jest to konsekwencją pełnienia przez ten ośrodek funkcji miasta stołecznego, co wiąże się z lokalizacją na jego obszarze urzędów administracji centralnej, siedzib dużych przedsiębiorstw krajowych i zagranicznych oraz innych podmiotów świadczących usługi wyższego rzędu. Tworzy to z Warszawy duży i chłonny rynek pracy o specyficznej strukturze zatrudnienia, z nadwyżkami pracujących w wielu sekcjach PKD.

W pozostałych miastach różnice w wielkości bazy ekonomicznej nie są już tak znaczące, niemniej do ośrodków o dużej wielkości sektora egzogenicznego wyrażonego liczbą osób w nim pracujących należy zaliczyć przede wszystkim Kraków, Wrocław, Katowice i Poznań. Miasta te należały jednocześnie do ośrodków o dużych rozmiarach bazy ekonomicznej w ujęciu względnym, co świadczy o ich znaczeniu gospodarczym.

Należy też podkreślić, że w analizowanym okresie wielkość bazy ekonomicznej w ujęciu bezwzględnym zmniejszyła się w pięciu ośrodkach (Lublin, Zielona Góra, Warszawa, Opole i Katowice), z czego największy spadek zanotowano w Warszawie (o 15606 osób) i Katowicach (6380 osób), natomiast w odniesieniu do liczby ludności spadek wielkości bazy ekonomicznej zaobserwowano w sześciu ośrodkach: pięciu wymienionych wyżej i w Rzeszowie ${ }^{4}$. Największe spadki w ujęciu względnym zaobserwowano w Opolu (-2,35 p.p.), Katowicach (-1,74 p.p.) i Zielonej Górze $(-1,46$ p.p.).

Oprócz oszacowania wielkości ważnym elementem analizy miejskiej bazy ekonomicznej jest określenie jej struktury. W tym celu obliczono udział zatrudnienia nadwyżkowego w poszczególnych sekcjach PKD (według nomenklatury PKD 2007) w całkowitym zatrudnieniu w sektorze egzogenicznym badanych miast. Dane te dla roku 2015 przedstawiono w załączniku 1. Na podstawie uzyskanych wyników doko-

${ }^{3}$ Dla pozostałych miast wojewódzkich dane o wartości PKB nie są publikowane.

${ }^{4} \mathrm{~W}$ Rzeszowie było to spowodowane poszerzeniem granic administracyjnych miasta $\mathrm{W}$ roku 2010, czego skutkiem był znaczący wzrost liczby mieszkańców. 
Tabela 1. Wielkość bazy ekonomicznej miast wojewódzkich w latach 2008 i 2015

\begin{tabular}{|c|c|c|c|c|}
\hline \multirow[b]{2}{*}{ Miasto } & \multicolumn{2}{|r|}{2008} & \multicolumn{2}{|r|}{2015} \\
\hline & $\begin{array}{c}\text { Wlk. bazy } \\
\text { ekonomicznej } \\
\text { w os. }\end{array}$ & \begin{tabular}{|c|} 
Wlk. bazy \\
ekonomicznej jako \% \\
ogółu ludności
\end{tabular} & \begin{tabular}{|c|} 
Wlk. bazy \\
ekonomicznej \\
w os.
\end{tabular} & $\begin{array}{c}\text { Wlk. bazy } \\
\text { ekonomicznej jako \% } \\
\text { ogółu ludności }\end{array}$ \\
\hline Wrocław & 38340 & 16,35 & 51040 & 19,70 \\
\hline Bydgoszcz & 9056 & 7,77 & 9965 & 8,29 \\
\hline Toruń & 5334 & 8,22 & 7873 & 12,50 \\
\hline Lublin & 23819 & 21,46 & 22568 & 19,15 \\
\hline Gorzów Wielkopolski & 4195 & 10,47 & 5297 & 13,22 \\
\hline Zielona Góra & 6690 & 16,44 & 5864 & 13,78 \\
\hline Łódź & 19087 & 8,61 & 26107 & 11,35 \\
\hline Kraków & 46618 & 16,81 & 61287 & 19,64 \\
\hline Warszawa & 247161 & 29,80 & 231555 & 27,30 \\
\hline Opole & 11422 & 25,23 & 7966 & 15,42 \\
\hline Rzeszów & 11959 & 15,35 & 12609 & 15,30 \\
\hline Białystok & 11986 & 14,39 & 13543 & 16,40 \\
\hline Gdańsk & 17592 & 12,57 & 24420 & 15,62 \\
\hline Katowice & 37267 & 28,58 & 30887 & 19,12 \\
\hline Kielce & 8382 & 11,64 & 11620 & 15,95 \\
\hline Olsztyn & 8142 & 12,87 & 8821 & 13,93 \\
\hline Poznań & 30854 & 13,54 & 33635 & 14,33 \\
\hline Szczecin & 15757 & 13,72 & 17284 & 15,87 \\
\hline
\end{tabular}

Źródło: obliczenia i opracowanie własne.

nano także klasyfikacji miast ze względu na sektorową strukturę zatrudnienia egzogenicznego. Zatrudnienie w poszczególnych sekcjach PKD zagregowano zatem do sektorów produkcji i obliczono ich udział w liczbie pracujących w sektorze egzogenicznym. Uwzględnione sektory to ${ }^{5}$ :

- $\operatorname{przemysł}(\mathrm{P})$ - sekcje B, C, D, E, F'

- $\quad$ usługi rynkowe (R) - G, H, I, J, K, L, M, N, R, S, T, U;

- usługi nierynkowe $(\mathrm{N})-\mathrm{O}, \mathrm{P}, \mathrm{Q}$.

${ }^{5} \mathrm{~W}$ żadnym $\mathrm{z}$ badanych miast $\mathrm{w}$ strukturze pracujących $\mathrm{w}$ działalności egzogenicznej nie zaobserwowano zatrudnienia w rolnictwie, więc sektor ten pominięto.

${ }^{6}$ Zgodnie z nomenklaturą PKD 2007 sekcje obejmują: A - rolnictwo, leśnictwo, łowiectwo i rybactwo, B - górnictwo i wydobywanie, C - przetwórstwo przemysłowe, D - wytwarzanie i zaopatrywanie w energię elektryczną, gaz, E - dostawę wody i gospodarowanie odpadami, F - Budownictwo, $\mathrm{G}$ - handel i naprawa pojazdów samochodowych, $\mathrm{H}$ - transport i gospodarka magazynowa, I - zakwaterowanie i gastronomia, $\mathrm{J}$ - informacja i komunikacja, $\mathrm{K}$ - działalność finansowa i ubezpieczeniowa, $\mathrm{L}$ - obsługa rynku nieruchomości, $\mathrm{M}$ - działalność profesjonalna, naukowa i techniczna, $\mathrm{N}$ - administrowanie i działalność wspierająca, $\mathrm{O}$ - administracja publiczna i obrona narodowa, obowiązkowe zabezpieczenia społeczne, $\mathrm{P}$ - edukacja, $\mathrm{Q}$ - opieka zdrowotna i pomoc społeczna, $\mathrm{R}$ - działalność związana z kulturą, rozrywką i rekreacją, S, T, U - działalność usługowa pozostała. 
Przy określaniu typu miasta ze względu na sektorową strukturę pracujących w działalności podstawowej posłużono się metodyką trójkąta Osaana. Zgodnie z nią miasta o typach P, R, N obejmują ośrodki, w których jeden z sektorów charakteryzuje się większą liczbą pracujących niż pozostałe sektory łącznie. Typy mieszane (PR, PN, RP itd.) obejmują miasta o względnej lub bezwzględnej dominacji jednego z sektorów $(37,5-75,0 \%)$ oraz dużym udziałem drugiego z sektorów, nieprzekraczającym jednak $50 \%$ pracujących. Wreszcie struktura, w której każdy z sektorów cechuje się udziałem w całkowitej liczbie pracujących w przedziale 25,0-50,0\%, nazywana jest zrównoważoną. Szczegółowe dane na temat sektorowej struktury bazy ekonomicznej badanych ośrodków przedstawiono w tabeli 2.

Biorąc pod uwagę współczesne uwarunkowania wzrostu i rozwoju gospodarczego, najbardziej korzystną strukturą produkcji charakteryzują się jednostki, w których największy udział w wolumenie wytwarzanych dóbr mają usługi rynkowe. Wynika to z faktu, że usługi rynkowe charakteryzują się wyższą wartością dodaną, szczególnie $\mathrm{w}$ porównaniu z produkcją przemysłową dóbr standaryzowanych. W związku z tym generują one większe strumienie dochodów napływających do lokalnej gospodarki, silniej stymulując jej rozwój. Ponadto, jak pokazują wyniki analiz Christofakisa i Gkouzosa, związki przedsiębiorstw usługowych z innymi, lokalnymi podmiotami są silniejsze, co przyczynia się do podniesienia poziomu kapitału społecznego oraz zwiększa stabilność lokalnych systemów społeczno-gospodarczych [por. Christofakis, Gkouzos 2014].

W 2015 r. w 11 na 18 miast wojewódzkich w strukturze pracujących w działalności egzogenicznej dominował sektor usług rynkowych. W porównaniu $\mathrm{z}$ rokiem 2008 liczba tego typu ośrodków wzrosła o 3 (były to: Torun - w 2008 r. o mieszanym typie produkcji RP, Zielona Góra - RN i Szczecin - RN). Dominacja usług rynkowych była charakterystyczna dla ośrodków charakteryzujących się największą liczbą mieszkańców oraz względnie dużymi rozmiarami bazy ekonomicznej. W grupie tej największy udział w strukturze pracujących w działalności egzogenicznej miały sekcje:

- $\quad \mathrm{N}$ (administrowanie i działalność wspierająca) - przeciętnie 21,4\% pracujących w sektorze egzogenicznym było zatrudnionych w tym rodzaju działalności; zatrudnienie w tej sekcji było względnie największe w Łodzi (34,9\%), a najmniejsze w Warszawie (5,7\%);

- J (informacja i komunikacja) - średnio 16,3\% pracowników sektora egzogenicznego tej grupy miast znalazło w niej zatrudnienie, najwięcej (26,2\%) we Wrocławiu, najmniej (0\%) w Toruniu i Zielonej Górze;

- K (działalność finansowa i ubezpieczeniowa) - przeciętny odsetek pracujących w tej sekcji wyniósł $12,6 \%$; najwięcej $(28,1 \%)$ w Warszawie, najmniej $(0 \%)$ w Zielonej Górze.

Najmniejsze znaczenie w tworzeniu miejsc pracy w sektorze egzogenicznym w tej grupie miast miały sekcje E (dostawa wody i gospodarowanie odpadami), B (górnictwo i wydobywanie), C (przetwórstwo przemysłowe) i D (wytwarzanie 
Tabela 2. Struktura pracujących w sektorze egzogenicznym miast wojewódzkich w latach 2008 i 2015 $(\mathrm{w} \%)$

\begin{tabular}{|l|c|c|c|l|c|c|c|l|}
\hline \multirow{3}{*}{ Miasto } & \multicolumn{4}{|c|}{2008} & \multicolumn{4}{c|}{2015} \\
\cline { 2 - 10 } & Przemysł & $\begin{array}{c}\text { Usługi } \\
\text { rynkowe }\end{array}$ & $\begin{array}{c}\text { Usługi } \\
\text { nierynkowe }\end{array}$ & Typ & Przemysł & $\begin{array}{c}\text { Usługi } \\
\text { rynkowe }\end{array}$ & $\begin{array}{c}\text { Usługi } \\
\text { nierynkowe }\end{array}$ & Typ \\
\hline Wrocław & 3,76 & 94,59 & 1,65 & $\mathrm{R}$ & 0,00 & 98,51 & 1,49 & $\mathrm{R}$ \\
\hline Bydgoszcz & 21,53 & 57,53 & 20,95 & $\mathrm{R}$ & 7,09 & 78,61 & 14,30 & $\mathrm{R}$ \\
\hline Toruń & 27,46 & 57,56 & 14,98 & $\mathrm{RP}$ & 12,92 & 76,87 & 10,22 & $\mathrm{R}$ \\
\hline Lublin & 15,68 & 25,03 & 59,29 & $\mathrm{NR}$ & 4,21 & 34,84 & 60,94 & $\mathrm{~N}$ \\
\hline Gorzów Wlkp. & 74,60 & 11,36 & 14,04 & $\mathrm{P}$ & 43,49 & 45,73 & 10,78 & $\mathrm{RP}$ \\
\hline Zielona Góra & 4,04 & 69,92 & 26,04 & $\mathrm{RN}$ & 3,85 & 59,89 & 36,26 & $\mathrm{R}$ \\
\hline Lódź & 2,45 & 77,97 & 19,57 & $\mathrm{R}$ & 0,28 & 78,23 & 21,48 & $\mathrm{R}$ \\
\hline Kraków & 12,31 & 74,18 & 13,51 & $\mathrm{R}$ & 8,88 & 83,26 & 7,86 & $\mathrm{R}$ \\
\hline Warszawa & 0,00 & 96,27 & 3,73 & $\mathrm{R}$ & 0,00 & 93,70 & 6,30 & $\mathrm{R}$ \\
\hline Opole & 10,81 & 52,72 & 36,47 & $\mathrm{RN}$ & 12,96 & 34,93 & 52,11 & $\mathrm{~N}$ \\
\hline Rzeszów & 18,17 & 53,70 & 28,13 & $\mathrm{RN}$ & 21,91 & 37,61 & 40,48 & $\mathrm{NR}$ \\
\hline Białystok & 5,20 & 40,18 & 54,63 & $\mathrm{NR}$ & 3,75 & 29,84 & 66,41 & $\mathrm{~N}$ \\
\hline Gdańsk & 11,34 & 65,58 & 23,08 & $\mathrm{R}$ & 11,51 & 83,36 & 5,13 & $\mathrm{R}$ \\
\hline Katowice & 9,08 & 80,55 & 10,37 & $\mathrm{R}$ & 0,00 & 96,98 & 3,02 & $\mathrm{R}$ \\
\hline Kielce & 9,41 & 42,65 & 47,94 & $\mathrm{NR}$ & 16,41 & 31,98 & 51,61 & $\mathrm{~N}$ \\
\hline Olsztyn & 3,63 & 60,36 & 36,01 & $\mathrm{RN}$ & 0,43 & 47,40 & 52,17 & $\mathrm{~N}$ \\
\hline Poznań & 0,00 & 98,73 & 1,27 & $\mathrm{R}$ & 0,00 & 95,88 & 4,12 & $\mathrm{R}$ \\
\hline Szczecin & 0,67 & 72,69 & 26,64 & $\mathrm{RN}$ & 1,51 & 61,88 & 36,61 & $\mathrm{R}$ \\
\hline
\end{tabular}

Źródło: obliczenia i opracowanie własne.

i zaopatrywanie w energię elektryczną). Przeciętnie w sekcjach tych pracowało odpowiednio $0 \%, 0,3 \%, 0,4 \%$ oraz $0,7 \%$ pracowników sektora egzogenicznego.

W przypadku 5 miast (Lublin, Opole, Białystok, Kielce, Olsztyn) w strukturze zatrudnienia egzogenicznego w 2015 r. dominowały usługi nierynkowe. Są to stolice województw o względnie niskim poziomie wzrostu gospodarczego, w większości położonych na tzw. ścianie wschodniej Polski. Wspólną cechą tych ośrodków jest także brak istotnych tradycji przemysłowych oraz niewielkie rozmiary bazy ekonomicznej. W roku 2008 wszystkie te miasta należały do typu mieszanego (NR, RN) pod względem sektorowej struktury zatrudnienia egzogenicznego. Świadczy to o stopniowym ujednolicaniu struktury produkcji w tych ośrodkach na rzecz usług nierynkowych.

Sekcjami PKD, które miały największy udział w ogólnej liczbie pracujących w sektorze egzogenicznym tej grupy miast w roku 2015, były sekcje O (administracja publiczna i obrona narodowa), Q (opieka zdrowotna i pomoc społeczna) oraz G (handel i naprawa pojazdów samochodowych) i P (edukacja). Przeciętnie było w nich zatrudnionych odpowiednio $25,4 \%, 17,6 \%, 13,7 \%$ i $13,6 \%$ pracowników sektora podstawowego. $\mathrm{Z}$ kolei najmniejsze zatrudnienie egzogeniczne odnotowano 
w sekcjach B, C, E, M i S, T, U, gdzie w ogóle nie odnotowano zatrudnienia egzogenicznego, oraz I, J, L, gdzie przeciętne zatrudnienie nie przekraczało $2 \%$ ogólnej liczby pracujących w działalności egzogenicznej. Przewaga usług nierynkowych może świadczyć o tym, że miasta te są względnie nieatrakcyjne $\mathrm{z}$ punktu widzenia potencjalnych inwestorów. W opinii autora może to wynikać z niekorzystnego położenia większości omawianych miast albo niskiego poziomu kapitału społecznego i ludzkiego oraz zjawiska tzw. drenażu mózgów. Dokładne określenie uwarunkowań tego stanu wymaga jednak odrębnych analiz. Można też z dużym prawdopodobieństwem założyć, że w długim okresie będzie to negatywnie oddziaływało na potencjał gospodarczy tych ośrodków oraz stanowiło barierę dla szybszego ich wzrostu gospodarczego.

Rozpatrując znaczenie bazy ekonomicznej jako stymulanty wzrostu gospodarczego ośrodków miejskich, należy dodatkowo uwzględnić stopień jej zróżnicowania. Niski stopień dywersyfikacji bazy ekonomicznej, monokultura produkcyjna, zwiększa podatność gospodarek lokalnych na cykliczne wahania koniunktury oraz spadek produkcji wywołany zmianą wielkości i struktury popytu zewnętrznego [Masik, Sagan 2016]. Ponadto, jak zauważa Knapik, warunkiem efektywnego zaspokajania potrzeb mieszkańców miasta oraz konsumentów zewnętrznych jest wysoki stopień dywersyfikacji bazy ekonomicznej [Knapik 2010, s. 43].

Jednym z mierników służących do pomiaru stopnia dywersyfikacji bazy ekonomicznej miast jest wskaźnik Amemiya (IED). Dokonując typologii ośrodków miejskich ze względu na stopień złożoności struktury sektora egzogenicznego, można wyróżnić miasta o strukturze mocno złożonej (IED $\leq 250)$, złożonej $(250<$ IED $\leq 500)$, jednorodnej $(500<$ IED $\leq 750)$ i mocno jednorodnej (IED > 750) [Knapik 2010, s. 45]. Wartości wskaźnika Amemiya obliczone dla miast wojewódzkich w latach 2008 i 2015 przedstawiono na rysunku 1.

Analiza tych danych pozwala stwierdzić, że w obu latach miasta wojewódzkie charakteryzowały się mocno złożoną bazą ekonomiczną. Wyjątkiem był Gorzów Wielkopolski, w którym wartości wskaźnika IED zawierały się w przedziale $250<$ IED $\leq 500$. Należy też jednak podkreślić, że w badanym okresie zmalał on z poziomu 447 jednostek w roku 2008 do 272 jednostek w 2015 r. Z punktu widzenia zapewnienia podstaw długotrwałego wzrostu gospodarczego badanych ośrodków miejskich negatywnie należy ocenić fakt, że w 10 z nich wartość wskaźnika IED wzrosła. W największym stopniu dotyczyło to Katowic (wzrost o 119 jednostek), Opola (73) i Gdańska (59). Spadki wartości wskaźnika IED zaobserwowano w 8 ośrodkach, były one jednak względnie niewielkie. Największe z nich (poza Gorzowem Wielkopolskim) dotyczyły Szczecina (-30 jednostek) i Białegostoku (-26). W efekcie średnia wartość wskaźnika IED dla wszystkich badanych miast wzrosła z poziomu $153 \mathrm{w}$ roku 2008 do $158 \mathrm{w} 2015$ r. Jest to wciąż relatywnie niski poziom, świadczący o wysokim stopniu dywersyfikacji bazy ekonomicznej, jednak utrzymywanie się tej tendencji w dłuższym okresie może zmniejszyć odporność badanych miast (urban resalience) na zewnętrzne załamania koniunktury gospodarczej. 


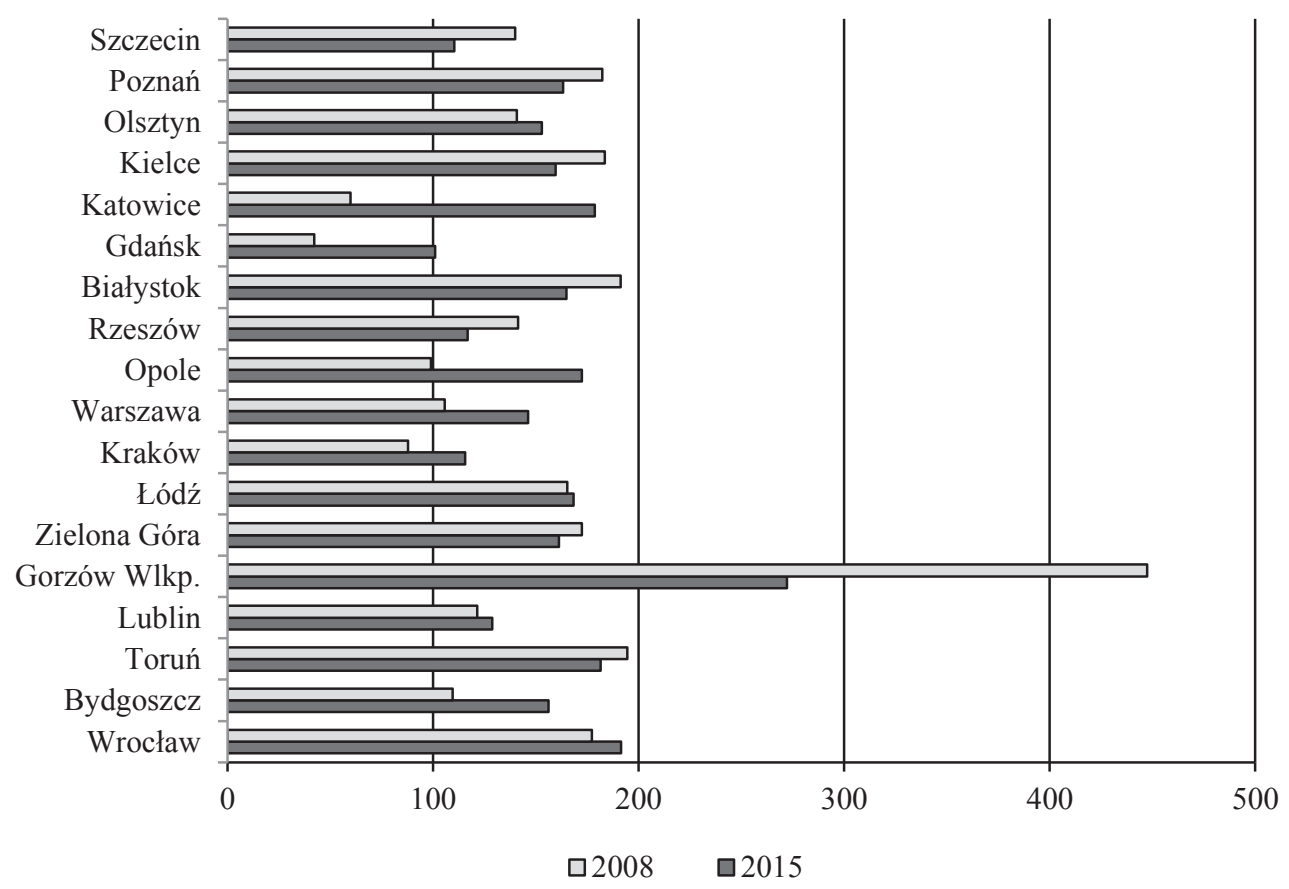

Rys. 1. Poziom zróżnicowania bazy ekonomicznej miast wojewódzkich w latach 2008 i 2015 Źródło: obliczenia i opracowanie własne.

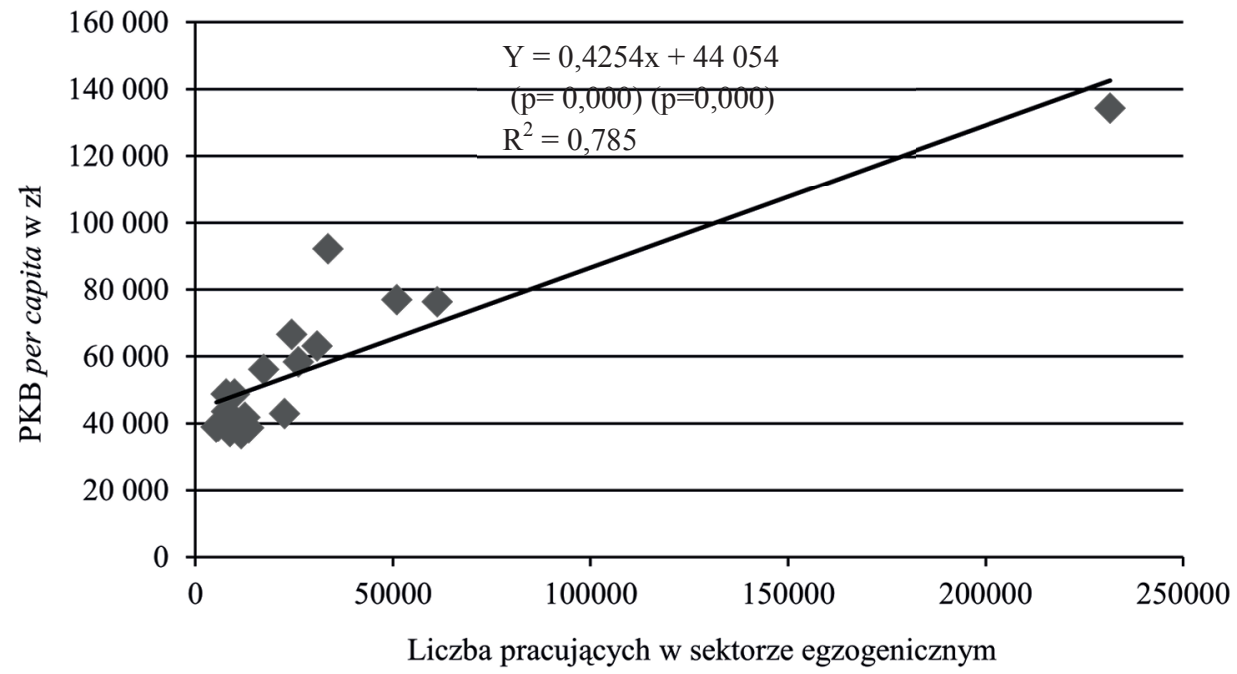

Rys. 2. Wielkość bazy ekonomicznej a wartość PKB per capita miast wojewódzkich w roku 2015 Źródło: obliczenia i opracowanie własne. 
Aby określić wpływ bazy ekonomicznej na wzrost gospodarczy miast wojewódzkich, wybrane wskaźniki charakteryzujące ich bazę ekonomiczną w roku 2015 zestawiono $\mathrm{z}$ wartościami PKB per capita $\mathrm{w}$ tym samym okresie. W pierwszym etapie analiz sprawdzono, czy wielkość bazy ekonomicznej, mierzona liczbą osób pracujących w sektorze egzogenicznym, miała wpływ na poziom wzrostu gospodarczego badanych jednostek. Wyniki przedstawiono w formie graficznej na rysunku 2. Na wykresie przedstawiono także funkcję regresji opisującą zależność między badanymi zmiennymi oraz wartość współczynnika determinacji $\mathrm{R}^{2}$.

Uzyskane wyniki pozwalają stwierdzić, że zgodnie z podstawowymi twierdzeniami teorii bazy ekonomicznej jej wielkość miała pozytywny wpływ na kształtowanie się wartości PKB per capita - wzrostowi zatrudnienia w działalności egzogenicznej towarzyszył wzrost poziomu wzrostu gospodarczego.

Uwagę zwraca wysoka wartość współczynnika determinacji, co wskazuje na dużą siłę obserwowanego związku. Wykluczenie ze zbioru badanych jednostek Warszawy, jako miasta o zdecydowanie największej wartości obu analizowanych zmiennych, nie zmienia wniosków co do zaobserwowanej zależności, choć wartość współczynnika determinacji zmalała do poziomu 0,67 . Podobne wyniki uzyskano także dla roku 2008, co sugeruje, że w badanych ośrodkach pozytywna zależność między wielkością bazy ekonomicznej a poziomem wzrostu gospodarczego ma trwały i uniwersalny charakter.

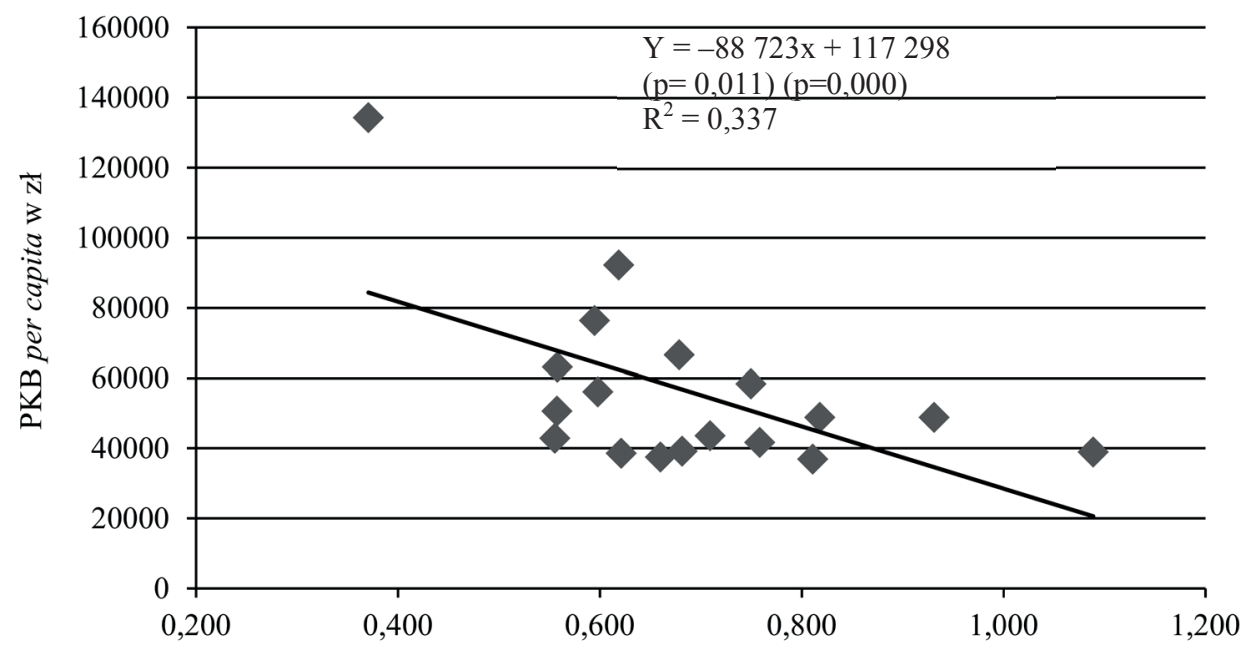

Specjalizacja lokalna w przemyśle

Rys. 3. Specjalizacja lokalna w przemyśle a poziom PKB per capita miast wojewódzkich w roku 2015 Źródło: obliczenia i opracowanie własne. 
W dalszej części badań przeprowadzono analizę, który z sektorów działalności egzogenicznej miał największy wpływ na poziom wzrostu gospodarczego badanych jednostek. W tym celu obliczono wskaźniki specjalizacji lokalnej dla każdego z wyróżnionych sektorów produkcji w roku 2015, a następnie zestawiono je z wartościami PKB per capita badanych jednostek. Wyniki przedstawiono na rysunkach 3, 4 i 5, a wartości obliczonych wskaźników specjalizacji lokalnej przedstawiono w załączniku 2.

Analiza danych zaprezentowanych na rysunku 3. pozwala stwierdzić, że wzrostowi specjalizacji w produkcji przemysłowej w ramach bazy ekonomicznej towarzyszył spadek wartości PKB per capita. Zatem sektor ten negatywnie oddziaływał na potencjał gospodarczy badanych ośrodków. Znajduje to także potwierdzenie w obliczonej funkcji regresji. Biorąc jednak pod uwagę niską wartość współczynnika determinacji oraz brak istotności statystycznej poszczególnych współczynników funkcji regresji, teza ta nie może być w pełni potwierdzona. W roku 2008 zależność między wartością współczynnika specjalizacji lokalnej w przemyśle dla badanych ośrodków a poziomem ich PKB per capita miała podobny charakter, jednak wartość współczynnika determinacji była na jeszcze niższym poziomie.

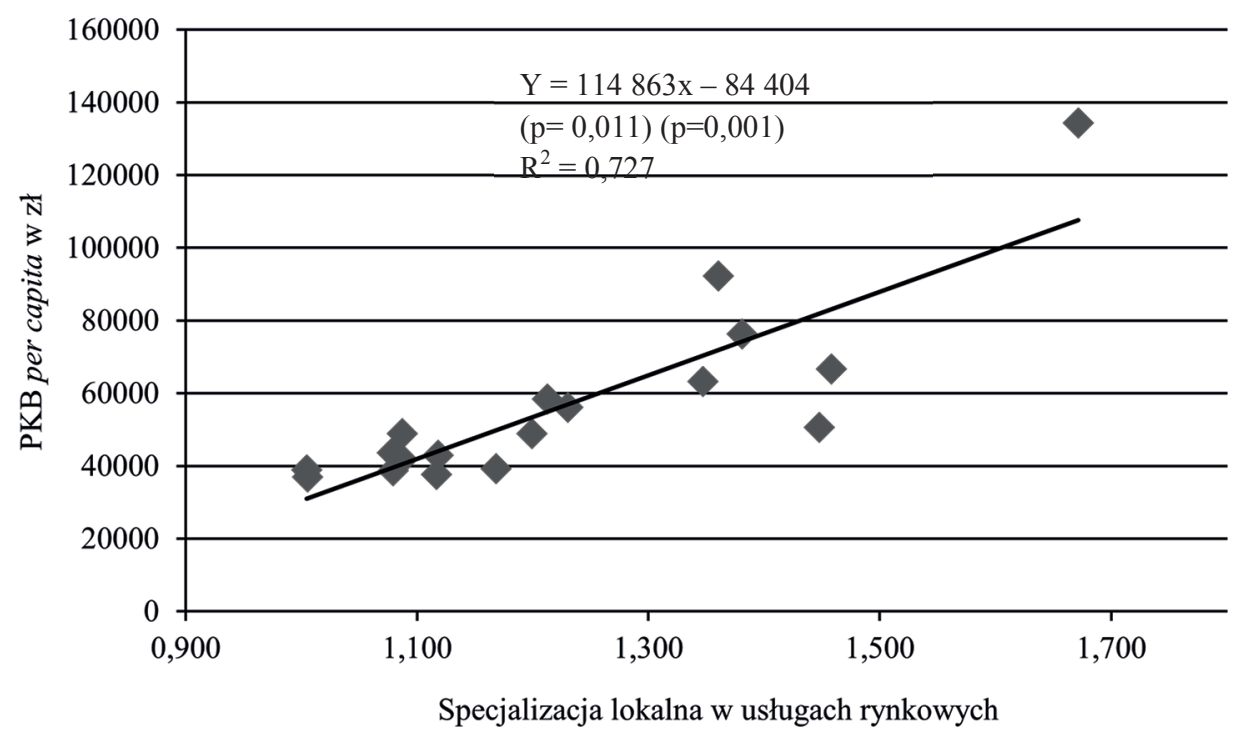

Rys. 4. Specjalizacja lokalna w usługach rynkowych a poziom PKB per capita miast wojewódzkich w roku 2015

Źródło: obliczenia i opracowanie własne.

W przypadku usług rynkowych zależność między współczynnikiem specjalizacji lokalnej a wartością PKB per capita była z kolei pozytywna (rys. 4). Zatem wzrost skali działalności w tym sektorze bazy ekonomicznej stymulował wzrost go- 
spodarczy badanych ośrodków. W tym wypadku również zwraca uwagę wysoka wartość współczynnika determinacji. Wyniki uzyskane dla roku 2008 były na podobnym poziomie. Średnie roczne tempo wzrostu PKB per capita w tej grupie ośrodków miejskich w latach 2008-2015 wyniosło 4,81\%.

Usługi rynkowe odgrywają także dominującą rolę w strukturze działalności gospodarczej wielu dużych ośrodków miejskich położonych w najbardziej rozwiniętych krajach Europy i świata. Obserwowanie podobnych tendencji w odniesieniu do wybranych miast $\mathrm{w}$ Polsce świadczy o udanym procesie transformacji ich gospodarek oraz rosnącym potencjale $\mathrm{w}$ zakresie ich uczestnictwa $\mathrm{w}$ międzynarodowych przepływach gospodarczych.

Z kolei dla usług nierynkowych uzyskane wyniki są podobne jak w przypadku specjalizacji lokalnej w przemyśle (rys. 5). Wzrost specjalizacji w usługach nierynkowych negatywnie oddziaływał na poziom wzrostu gospodarczego i to zarówno w roku 2015, jak i w 2008. Tezy tej nie można jednak jednoznacznie potwierdzić ze względu na niski poziom istotności statycznej parametrów estymowanej funkcji regresji oraz niską wartość współczynnika determinacji. Przeciętne roczne tempo wzrostu PKB per capita tej grupy miast było niższe niż miast o dominującej roli usług rynkowych i wyniosło $4,16 \%$.

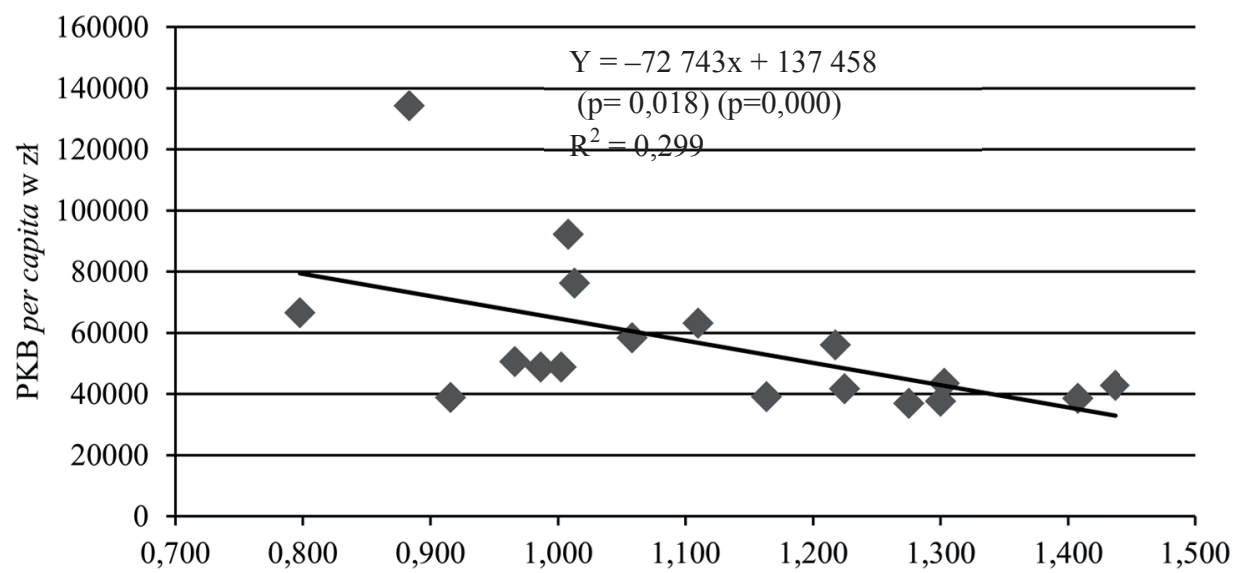

Specjalizacja lokalna w usługach nierynkowych

Rys. 5. Specjalizacja lokalna w usługach nierynkowych a poziom PKB per capita miast wojewódzkich w roku 2015

Źródło: obliczenia i opracowanie własne.

Wnioski tym zakresie są podobne do uzyskanych przez M. Dacko [2009] w odniesieniu do gmin województwa małopolskiego: wzrost specjalizacji małopolskich gmin w zakresie wytwarzania usług nierynkowych prowadził do spadku ich samodzielności budżetowej oraz wzrostu bezrobocia (w pozostałych sektorach Dacko za- 
obserwował podobne zależności jak w prezentowanych analizach). Autor ten zauważa, że głównym podmiotem odpowiedzialnym za zapewnienie odpowiedniej podaży usług nierynkowych są władze poszczególnych jednostek samorządu terytorialnego. Ich najważniejszymi odbiorcami są mieszkańcy wspólnot samorządowych. Podaż tych usług jest zatem dopasowywana do wielkości popytu lokalnego, rzadko więc wykraczają one poza granice danego miasta. Jedynie w odniesieniu do najbardziej popularnych szkół, szpitali, ośrodków zdrowia można mówić o ponadlokalnym znaczeniu świadczonych przez nie usług, co jest warunkiem pozytywnego oddziaływania na miejską gospodarkę [Dacko 2009, s. 32].

\section{Zakończenie}

Miejska baza ekonomiczna, definiowana jako te rodzaje działalności gospodarczej, której efekty są przeznaczone na rynek pozalokalny, jest postrzegana jako jedna z determinant wzrostu gospodarczego ośrodków miejskich. Wzrost skali i zakresu działalności egzogenicznej powoduje napływ dodatkowych dochodów do miasta, co pobudza popyt wewnętrzny i prowadzi do zwiększania produkcji.

Celem prezentowanych analiz było określenie wielkości, struktury oraz poziomu zróżnicowania bazy ekonomicznej miast wojewódzkich w Polsce. Zbadano także relacje między zmianami wielkości i struktury bazy ekonomicznej tych miast a poziomem wzrostu gospodarczego mierzonego wartością PKB per capita.

W ujęciu zarówno bezwzględnym, jak i względnym największą wielkością bazy ekonomicznej charakteryzowała się Warszawa. Dysproporcje w rozmiarach sektora egzogenicznego pomiędzy stolicą a pozostałymi miastami wojewódzkimi sięgają kilkuset procent i są większe, niż wynikałoby to z różnic w liczbie mieszkańców. Częściowo jest to zapewne uwarunkowane statusem administracyjnym Warszawy w krajowym systemie społeczno-gospodarczym. Jednocześnie świadczy o wysokiej konkurencyjności i atrakcyjności inwestycyjnej stolicy na tle innych ośrodków. W pozostałych miastach wojewódzkich największe rozmiary bazy ekonomicznej, także w ujęciu względnym, z reguły obserwowano w ośrodkach dużych - w Krakowie, Katowicach, we Wrocławiu i w Poznaniu. Zależność pomiędzy rozmiarami bazy ekonomicznej a wielkością badanego miasta nie była jednak wyraźna.

Analizując sektorową strukturę bazy ekonomicznej, można było wyróżnić dwie odrębne grupy miast. Pierwszą tworzyły miasta, w których dominującą rolę w strukturze działalności egzogenicznej odgrywały usługi rynkowe. Są to największe ośrodki miejskie, które z powodzeniem przeszły okres transformacji ustrojowej i obecnie odgrywają rolę ważnych regionalnych i krajowych węzłów gospodarki oraz biegunów wzrostu gospodarczego. Co istotne, w analizowanym okresie udział usług rynkowych w strukturze bazy ekonomicznej w każdym z tych ośrodków wzrósł. Drugą grupę stanowiły ośrodki miejskie, których sektor egzogeniczny opierał się na usługach nierynkowych. Do grupy tej należała większość stolic województw zaliczanych do tzw. ściany wschodniej Polski, a więc obszaru charakteryzującego się ni- 
skim poziomem wzrostu gospodarczego oraz niskim poziomem konkurencyjności regionalnej gospodarki, co znajduje odzwierciedlenie także w strukturze działalności egzogenicznej ich stolic. Bardziej szczegółowa analiza struktury bazy ekonomicznej tych ośrodków, uwzględniająca jej zróżnicowanie na poziomie sekcji PKD 2007, pozwala przypuszczać, że podstawę ich potencjału gospodarczego stanowią funkcje nabyte w ramach reformy administracyjnej z roku 1999.

Pozytywnie należy ocenić fakt, że poziom dywersyfikacji bazy ekonomicznej badanych ośrodków był wysoki. We wszystkich miastach, z wyjątkiem Gorzowa Wielkopolskiego, sektor działalności egzogenicznej należał do silnie zdywersyfikowanych. Zwiększa to odporność gospodarek badanych ośrodków na załamania popytu zewnętrznego i jednocześnie stwarza podstawy dla bardziej długotrwałego i harmonijnego wzrostu gospodarczego.

Przeprowadzone analizy dają także podstawy do pozytywnej weryfikacji tezy o znaczeniu bazy ekonomicznej jako stymulanty wzrostu gospodarczego miast. Ośrodki o relatywnie dużej bazie ekonomicznej charakteryzowały się wyższym poziomem PKB per capita. Odwrotnie było w miastach o niewielkich rozmiarach bazy ekonomicznej. Uwzględniając strukturę sektorową działalności egzogenicznej prowadzonej w badanych ośrodkach, można także zauważyć, że wyższym poziomem wzrostu gospodarczego cechowały się miasta o dominującej roli sektora usług rynkowych. Niższy poziom PKB per capita był z kolei obserwowany w ośrodkach, w których podstawę bazy ekonomicznej stanowiły usługi nierynkowe.

Rozpatrując powyższe wnioski w kontekście poziomu spójności gospodarczej na poziomie lokalnym i regionalnym, w opinii autora można będzie się spodziewać dalszego wzrostu dysproporcji w poziomie wzrostu gospodarczego. PKB per capita miast o konkurencyjnej, nowoczesnej strukturze produkcji (o czym świadczy dominacja usług rynkowych w bazie ekonomicznej) będzie zwiększał się w szybszym tempie, dając podstawy do wzmocnienia ich potencjału endogenicznego, a także dalszego wzrostu bazy ekonomicznej. Uwzględniając lokalizację miast wojewódzkich o niskim poziomie konkurencyjności bazy ekonomicznej oraz biorąc pod uwagę znaczenie ośrodków miejskich w stymulowaniu rozwoju gospodarczego regionów, można się także spodziewać, że regionalne dysproporcje rozwojowe w Polsce również będą się zwiększały głównie w relacji wschód-zachód. Przełamanie tych tendencji będzie wymagało dalszej reorientacji polityki spójności w kierunku wzmacniania potencjału gospodarczego miast położonych na tzw. ścianie wschodniej.

\section{Literatura}

Christofakis M., Gkouzos A., 2014, Exploration of Localness in the Context of Economic Base: Accessing Evidence From Greek Prefectures, Urban \& Regional Development Studies, no. 26, s. 189-202.

Dacko M., 2008, Badanie stanu bazy ekonomicznej $i$ struktury funkcjonalnej gmin województwa matopolskiego metodami pośrednimi, Folia Pomeranae Universitatis Technoloiae Stetinensis, nr 268, s. 25-34. 
Jerczyński M., 1971, Metody pośrednie identyfikacji i pomiaru bazy ekonomicznej miast, [w:] Baza ekonomiczna i struktura funkcjonalna miast, Prace Geograficzne, nr 87, Instytut Geografii Polskiej Akademii Nauk, Warszawa, s. 111-141.

Knapik W., 2010, Zmiany struktury funkcjonalnej miast województwa tódzkiego w latach 2000-2008, [w:] Studia nad bazą ekonomiczną miast i rynkiem pracy w województwie łódzkim, red. Wójcik M., Karpacki Instytut Rozwoju Regionalnego, Nowy Sącz, s. 32-56.

Korcelli P., 2007, Podstawowe węzty uktadu osadniczego w Polsce na tle europejskiego systemu osadniczego (Aglomeracje-Metropolie), PAN, Komitet Przestrzennego Zagospodarowania Kraju, Warszawa.

Krikelas A.C., 1992, Why regions grow: A Review of Research On the Economic Base Model, Economic Review, no. 7, s. 16-29.

Markusen A., 2007, A consumption Base Theory of Development: An Application to the Rural Cultural Economy, Agriculture and Resource Economics Review, no. 36, s. 9-23.

Masik G., Sagan I., 2016, Strategie i instrumenty wspierajace odporność gospodarcza. Przykład wybranych regionów europejskich, Studia Regionalne i Lokalne, nr 4 (66), s. 5-29.

Rutland T., O'Hagan S., 2007, The Growing Localness of the Canadian City, or, On the Continued (Ir) relevance of Economic Base Theory, Local Economy no. 2 (22), s. 163-185.

Skrzyp J., 2002, Polityka rozwoju regionalnego. Wybrane zagadnienia, Wydawnictwo Akademii Podlaskiej, Siedlce, s. 18.

Sokołowski D., 2008, Baza ekonomiczna większych miast w Polsce w okresie transformacji systemowej, Przegląd Geograficzny, nr 80, s. 245-266.

Sridhar K.S., 2017, Economic change and specialization in India 's Cities, Review of Urban \& Regional Development Studies, vol. 29, no. 1, s. 63-87.

Stawasz D., 2016, Współczesne dylematy zarządzania rozwojem miast, Wydawnictwo Uniwersytetu Łódzkiego, Łódź.

Strahl D., 2009, Klasyfikacja europejskiej przestrzeni regionalnej ze względu na rozwój gospodarczy i gospodarke oparta na wiedzy, Prace Naukowe Uniwersytetu Ekonomicznego we Wrocławiu, nr 46, s. 15-26.

Walkiewicz D., 2006, Przemiany struktury funkcjonalnej miast wojewódzkich w latach 1975-1995, Wydawnictwo Uniwersytetu Łódzkiego, Łódź. 
Załącznik 1. Struktura pracujących w sektorze egzogenicznym miast wojewódzkich w 2015 r. według sekcji PKD (w \%)

\begin{tabular}{|c|c|c|c|c|c|c|c|c|c|c|c|c|c|c|c|c|c|c|}
\hline o & B & $\mathrm{C}$ & $\mathrm{D}$ & $\mathrm{E}$ & $\mathrm{F}$ & G & $\mathrm{H}$ & I & $\mathrm{J}$ & $\mathrm{K}$ & $\mathrm{L}$ & $\mathrm{M}$ & $\mathrm{N}$ & $\mathrm{O}$ & $\mathrm{P}$ & $\mathrm{Q}$ & $\mathrm{R}$ & $\mathrm{S}, \mathrm{T}, \mathrm{U}$ \\
\hline Wrocław & 00 & 0,00 & 0,00 & 0,00 & 0,00 & 0,00 & 0,00 & 2,42 & 26,16 & 18,24 & 0,00 & 21,89 & 28,92 & 0,00 & 0,00 & 1,49 & 0,52 & 0,36 \\
\hline Bydgo & 0 & 4,28 & 80 & 0,00 & 0,00 & 0,00 & 0,00 & 91 &, 09 & 10,58 & 12,68 & 0,00 & 1,36 & 0,48 & 00 & 13,82 & 0,00 &, 00 \\
\hline Toruń & ( & 0,00 & 0,00 & 0,00 & 12,92 & 41,76 & 0,00 & 44 & 0,00 & 2,96 & 6,62 & 6,61 & 12,97 & 5,89 & 33 & 0,00 & 50 & 00 \\
\hline Lublin & 00 & 0,00 & 2,61 & 0,00 & 1,61 & 12,89 & 0,00 & 0,00 & 4,05 & 11,52 & 2,90 & 0,00 & 1,91 & 9,95 & 27,63 & 23,36 & 1,56 & 0,00 \\
\hline Gorzów Wiel & 0,00 & 39,44 & 4,05 & 0,00 & 0,00 & 0,00 & 0,00 & 0,00 & 0,00 & 0,00 & 0,00 & 0,00 & 36,50 & 10,78 & 0,00 & 0,00 & 0,00 & 9,23 \\
\hline Zielor & 85 & 00 & 0,00 & 0,00 & 0,00 & 28,71 & 3,16 & 0,00 & 0,00 & 0,00 & 7,95 & 0,00 & 11,67 & 30,63 & 5,64 & 0,00 & 3,60 & 4,80 \\
\hline Łódź & 00 & 00 & 0,28 & 0,00 & 0,00 & 4,78 & 0,00 & 0,00 & 10,82 & 15,01 & 2,52 & 7,99 & 34,96 & 0,00 & 0,00 & 21,48 & 0,51 & 1,64 \\
\hline Хакоw & 00 & 00 & 0,00 & 0,00 & 8,88 & 4,66 & o, 00 & 7,18 & 25,41 & 9,50 & 0,00 & 24,54 & 9,87 & 0,00 & 3,84 & 4,02 & 1,52 & 0,57 \\
\hline Warszav & 0,00 & 00 & 0,00 & 0,00 & 0,0 & 5,01 & 1,60 & 2,38 & 18,36 & 28,09 & 4,72 & 25,59 & 5,74 & 6,30 & 0,00 & 0,00 & 1,30 & 0,91 \\
\hline Opol & & ,00 & 3,86 & & & & 13,40 & & & & 0,00 & 0,00 & 15,79 & & 00 & 14,72 & 4,04 & 00 \\
\hline & & 0,00 & 4,99 & & & & 0,00 & & & & $0,4 \mathrm{~J}$ & & 14,28 & & 00 & 17,23 & 0,00 & 00 \\
\hline & 0,00 & 0,00 & 3,00 & & & 23,19 & 0,00 & 2,66 & & & 0,95 & & 3,05 & 17,79 & 27,85 & 20,76 & 0,00 & 00 \\
\hline Gdańsk & 0,00 & 0,00 & 2,71 & 0,00 & & 5,62 & 1,63 & 3,14 & 23,08 & 17,75 & 3,13 & 6,73 & 20,62 & 0,00 & & 0,00 & 1,01 & 0,65 \\
\hline Katowic & 0,00 & 0,00 & 0,00 & 0,00 & 0,00 & 0,00 & 0,54 & 0,00 & 23,90 & 21,89 & 2,18 & 12,22 & 31,37 & 0,60 & 0,00 & 2,42 & 4,87 & 0,00 \\
\hline Kielce & 0,00 & 0,00 & 1,44 & 0,00 & 14,97 & 20,48 & 0,00 & 1,35 & 0,00 & 0,00 & 0,00 & 0,00 & 6,80 & 27,00 & 0,00 & 24,61 & 3,35 & 0,00 \\
\hline Olsztyn & 0,00 & 0,00 & 0,43 & 0,00 & 0,00 & 10,28 & 3,64 & 1,43 & 4,11 & 5,12 & 1,23 & 0,00 & 19,79 & 35,12 & 12,74 & 4,31 & 1,79 & 0,00 \\
\hline Poznań & 0,00 & 0,00 & 0,00 & 0,00 & 0,00 & 10,23 & 0,28 & 1,69 & 17,67 & 10,63 & 0,53 & 20,48 & 33,33 & 1,47 & 2,64 & 0,00 & 0,00 & 1,04 \\
\hline Szczecin & 0,00 & 0,00 & 1,51 & 0,00 & 0,00 & 1,68 & 25,20 & 2,92 & 11,12 & 4,10 & 1,28 & 0,00 & 14,42 & 18,51 & 14,78 & 3,32 & 1,16 & 0,00 \\
\hline
\end{tabular}

Źródło: obliczenia i opracowanie własne. 
Załącznik 2. Wskaźniki specjalizacji lokalnej w miastach wojewódzkich w latach 2008 i 2015

\begin{tabular}{|c|c|c|c|c|c|c|}
\hline \multirow{2}{*}{ Miasto } & \multicolumn{3}{|c|}{2008} & \multicolumn{3}{|c|}{2015} \\
\hline & Przemysł & Usługi rynkowe & Usługi nierynkowe & Przemysł & Usługi rynkowe & Usługi nierynkowe \\
\hline Wrocław & 0,63 & 1,43 & 0,98 & 0,56 & 1,45 & 0,97 \\
\hline Bydgoszcz & 0,96 & 1,05 & 1,03 & 0,93 & 1,09 & 1,00 \\
\hline Toruń & 0,95 & 1,08 & 1,00 & 0,82 & 1,20 & 0,99 \\
\hline Lublin & 0,63 & 1,05 & 1,49 & 0,56 & 1,12 & 1,44 \\
\hline Gorzów Wielkopolski & 1,12 & 0,92 & 0,95 & 1,09 & 1,00 & 0,92 \\
\hline Zielona Góra & 0,63 & 1,32 & 1,13 & 0,68 & 1,17 & 1,16 \\
\hline Łódź & 0,83 & 1,16 & 1,06 & 0,75 & 1,21 & 1,06 \\
\hline Kraków & 0,68 & 1,32 & 1,05 & 0,60 & 1,38 & 1,01 \\
\hline Warszawa & 0,41 & 1,80 & 0,77 & 0,37 & 1,67 & 0,88 \\
\hline Opole & 0,75 & 1,35 & 0,91 & 0,71 & 1,08 & 1,30 \\
\hline Rzeszów & 0,80 & 1,14 & 1,14 & 0,76 & 1,09 & 1,22 \\
\hline Białystok & 0,70 & 1,12 & 1,31 & 0,62 & 1,08 & 1,41 \\
\hline Gdańsk & 0,73 & 1,23 & 1,11 & 0,68 & 1,46 & 0,80 \\
\hline Katowice & 0,64 & 1,64 & 0,66 & 0,56 & 1,35 & 1,11 \\
\hline Kielce & 0,81 & 1,09 & 1,21 & 0,81 & 1,01 & 1,28 \\
\hline Olsztyn & 0,71 & 1,20 & 1,18 & 0,66 & 1,12 & 1,30 \\
\hline Poznań & 0,68 & 1,36 & 0,99 & 0,62 & 1,36 & 1,01 \\
\hline Szczecin & 0,69 & 1,25 & 1,13 & 0,60 & 1,23 & 1,22 \\
\hline
\end{tabular}

Źródło: obliczenia i opracowanie własne. 